\title{
Some Connections of Africa and the U.S.A in American World Literature
}

\author{
Louis Mendy \\ Professor at Cheikh Anta Diop University, Dakar, Senegal
}

\begin{abstract}
The plots in some novels by Nathaniel Hawthorne, Toni Morrison, Maya Angelou and Paule Marshall, to name but a few, remind the African readers of some sociological realities on the black continent. That interconnection of Africa and the U.S.A., through literature, reinforces the idea of American literature as world literature.

If the U.S.A. was a child, we could assert that his or her parents are Africa and Europe thanks to their irrefragable contributions to the making of the country. There is undoubtedly an interconnection of Africa and the USA in quite a few fields, especially in works of fiction

Kimberly Crenshaw's feminist theory of intersectionality is very much present in quite a few American novels. In Nathaniel Hawthorne's The Scarlet Letter, the ostracism of Hester Prynne, a wife in seventeenth-century Puritan America, after she gave birth to an illegimate child, is tantamount to a "social death" in Africa, where women are still required to be paragons of virtue, especially when they are married. Under no circumstances, should espoused women, in many African societies have paramours and indulge in such a turpitude. Obinna Udenwe expounds on that issue in her short story "Bedfellows." In Maya Angelou's Gather Together in My Name, Rita's early pregnancy is similarly a poignant problem in Africa, where some girls are married as young as 12 or 13. That situation recurs in Toni Morrison's The Bluest Eye, with Pecola who is impregnated at 12. As for Paule Marshall, her novel Praisesong for a Widow is full of African cultural representations and supernatural rites like the ceremony of "lave tête".
\end{abstract}

Key words: African literature, American literature, cultural representations girl-pregnancy, interconnection, intersectionality, world literature.

\section{Introduction}

If the USA was a child, we could undoubtedly assert that his or her parents are Africa and Europe. Although it is generally admitted that America was discovered by Christopher Columbus, quite a few afro centrists strongly claim that Black Africans sailed to the American continent a long time before the White Europeans such as the Puritans from England in the early $17^{\text {th }}$ century. However, the well documented time of Blacks' immigration into America is unfortunately more specifically about slavery. Consequently, the millions of enslaved people from Africa have immensely contributed to the making of today's USA with their hard work, religions, songs and beliefs since they set foot on that continent.

Thus, it is quite obvious that there are some connections of the USA and Africa in a lot of domains. After the abolition of slavery, and the possibility for African Americans to be highly educated, their literary productions naturally enriched American Literature as a whole. This paper examines the close link between the two continents in some American works of fiction: The Scarlet Letter (1850) by Nathaniel Hawthorne, Praisesong for the Widow (1983) by Paule Marshall, The Bluest Eye (1970) by Toni Morrison and Gather Together in My Name (1985) by Maya Angelou. Although the time frame between the first book and the last one is more than one hundred years; that certainly proves that part of American Literature has progressively evolved from a national into a global phenomenon, with themes that recall aspects of African culture.

The first section of this paper expounds on our possible understanding of American World Literature, then the second one focuses on the lot of some American women which echoes the same problematic in African women's living conditions, such as the phenomenon of women's adultery, young girls' pregnancies and 
motherhood in some American novels. The last one lays emphasis on some religious rites and cultural practices in Praisesong for the Widow that are akin to some African cultural realities described in a novel like the Concubine by Elechi Amadi. That presence of Africa in American fiction largely participates in framing American Literature as World Literature since it can be extensively read and understood in Africa and globally.

\section{American Literature as World Literature.}

For Wai Chee Dimock, "'in a globalizing age, studying American Literature in isolation from the rest of the world seems less and less justified"' (Dimock 2007, 305). If we take into account the history of the making of that continent, and more precisely the making of the United States of America, Dimock's assertion is very relevant. We all know that the USA is a combination of nearly all parts of the rest of the world. No wonder then, American Literature, although based on the culture and history of that country, encapsulates bits of other cultures and histories. That hybridity of American culture and way of life, known today as multiculturalism obviously transpires in the works of fiction produced in the country; and for Jeffrey R Di Leo:

American World Literature refers to the intersections of the global dimensions of American Literature and its representations of itself in the largest world with other literatures in English, whether originally so or via the commercial culture of rapid and pervasive translation.( $\mathrm{Di}$ Leo, 2016, 2)

It is therefore of paramount importance to think American as global. Thus, the de-territorialization of American literature becomes a necessity for Academics. According to Paul Giles:

More specifically, I will contend that the association of America, and by extension the subject of American Literature, with the current geographical boundaries of the United States is a formulation that should be seen as confined to a relatively limited and specific in history, roughly the period between the end of the American Civil War in 1865 and the presidency of Jimmy Carter which ended in 1980. (Giles, 2007, 39)

The fact of understanding American Literature as world literature is also accepted by many scholars thanks to the language in which it is written. The hegemony of the English language as the first international language that is studied almost everywhere in the world makes American Literature a world property. However, some academics strongly believe that the use of English alone cannot make it world Literature, but rather the Anglo-globalism of its themes that relate to other parts of the world. For Susan Stanford Friedman:

'A planetary consciousness about American literary cultures requires thinking beyond the temporal and spatial boundaries that justified its expansion ever westward with the notion of Manifest Destiny to rule the North of American continent" (Friedman, 2007, 62).

Thus African academics need to understand that American Literature can be viewed as world literature because it is extensively read and taught in Africa, as well as in other parts of the world. The situation of American women and girls in some American works of fiction is often very similar to the lot of African women and girls in African novels.

\section{The Lot of Women in some American works of fiction.}

Kimberly Crenshaw's feminist theory of intersectionality can be applied in the lives of quite a few American and African women. The hardships in women's living conditions in both continents are quite similar in some works of fiction, like the Scarlet Letter by Nathaniel Hawthorne, Gather together in my Name by Maya Angelou, the Bluest Eye by Toni Morrison and Bedfellows by Obinna Odenwe to name but a few. No wonder then, that several women in other parts of the world like Oceania and Asia, certainly face the same problems.

In fact, for Kimberly Crenshaw, American women, especially African American ones, face too many stumbling blocks in their lives because of men's domination and selfishness In that vein Gabriel Lugo writes: 
"In other words, intersectionality theory asserts that people are often disadvantaged by multiple sources of oppression, their race, class, gender, identity, religion, sexual orientation and other identity markers". (Lugo, 2016, 1).

If we refer to The Scarlet Letter by Nathaniel Hawthorne, set in seventeenth-century Puritan America, Hester Prynne first undergoes the oppression of being married to somebody she does not love. On top of that, her husband decides to send her to settle alone in Boston, while he travels around the world in search of knowledge. Her second oppression, from the society, concerns her ostracism after she has found a man she really loves and the birth of her illegimate child. For the puritan society of Boston, Hester Prynne is an adulteress and is stigmatized as a bad woman, a sinner who should face capital punishment. In fact, in that time, adultery was a deadly sin and Hawthorne reports an old woman's words:

This woman has brought shame upon us all and ought to die. Is there no law for it? Truly there is, both in the Scripture and the State-book. Then the magistrates, who have made it of no effect, thank themselves if their own wives and daughters go astray (Hawthorne, 1850, 49).

For the Puritan male-dominated society, adultery was only committed by women and never by men who were only guilty of fornification For Carol Karlsen, "part of woman's sin, then, was the seduction of man, another was the failure to serve" (Carol Karlsen, 1989, 176). Hester Prynne is seen by puritan men as a woman who has seduced her paramour or illicit lover and has refused to serve her husband.

The story about Hester Prynne echoes the situation of some African women in forced marriages and who have fallen in love afterwards with other men in some African novels. It is quite unacceptable for a woman in many African societies to express her love for a man that has not been chosen by her parents or relatives. Like Hester Prynne, those women are socially considered as people deprived of sentiments and who, therefore, have no say in matters related to their emotions for partners of their choices.

Hester Prynne's story could be heard in many communities in the world, especially in Africa. In some Arabic countries using the Sharia Law for instance, such a woman could face stoning to death. Obinna Odenwe confirms that in his short story Bedfellows: According to Udo Okoronkwo-Chukwu:

Bedfellows is an exploration into society's oldest institution and the idea of what is normal. It offers a closer look into one of Nigerian society's taboos - marital infidelity on the part of women. The representation of infidelity in marriage by a woman becomes a parody of the customs and beliefs that guarantee masculine liberty in the institution. (Okoronkwo-Chukwu, 2016, 1)

In the Northern part of Nigeria, the Sharia Law is mostly used to punish women guilty of adultery. Hawthorne's story about Hester Prynne has constantly reminded, any reader from any country, of the weight of the patriarchal system on women in many countries in the world.

In The Awakening by Kate Chopin, the patriarchal order is such a stronghold that women who attempt to challenge it are likely to be crushed: Edna, the protagonist in the story faces a lot of social prejudices because of her behavior. For Louis Mendy:

However, Edna epitomizes her challenge of the patriarchal order of her community, when she openly decides to seek her sexual independence. In so doing, she becomes an adulterous woman and is seen as a whore by some people. (Mendy 2017, 37)

Hester Prynne succumbs, in the end, to the Puritan punctilious order by accepting to wear the Letter A and by rusticating far from the city because of the ostracism she is a victim of. In the same vein, Edna also fails to transform the patriarchal order in her community. Louis Mendy adds: "since she has attempted to adopt a way of life that is unconceivable in a patriarchal society, Edna finally loses her battle and her life by committing suicide" (Mendy 2017, 44) 
The theory of intersectionality can be widely used in many women's lives in the world and more dramatically in Africa where women are often oppressed for many different reasons. Quite a few American fiction stories seem to have been written, not only for Americans but also for the whole world.

Apart from women, some girls also live in horrible situations in some American works of fiction and that echoes the reality of girls' living conditions in quite a few African novels. Writers like Toni Morrison and Maya Angelou have execrated girls' ordeals in some of their works of fiction.

When Africans and probably people in other continents read The Bluest Eye by Toni Morrison or Gather Together in My Name by Maya Angelou, they certainly feel that the stories also reflect some social realities of their communities. Girls are not grown-ups and never should they undergo the same hardships as adults. Unfortunately, because of poverty and some cultural values, girls sometimes do not enjoy their girlhood, in so far as they directly move from infanthood to adulthood, especially when it comes to sex.

The problem is so rampant in Africa that Rita's story in Gather Together in My Name and Pecola's ordeal in The Bluest Eye recall some African girls' tragic lives in quite a few African works of fiction. Pecola is pregnant at the age of twelve and Rita at seventeen. Early pregnancies are not only common to American and African societies, but also to many other world communities. Thus, through those two books, both Morrison and Angelou seize the opportunity to raise a world concern. According to the United Nations Population Fund, "Sub Saharan Africa had the highest prevalence of teenage pregnancy in the world in 2013" (United Nations Population Fund 2013).

The reasons for teenage pregnancy may differ from one part of the world to another. Nevertheless, it is generally admitted that the consequences on the girl's health and life are similar everywhere. If the pregnant girls are lucky enough to survive the pain of giving birth, their status of girl-mother is a parlous one. For Louis Mendy again: "Girls are not expected to become mothers at seventeen, in so far as they are not physically, sociologically and psychologically mature enough to enter the world of adults" (Mendy, 2018, 1104).

Being a mother at seventeen, and poor into the bargain, Rita is easily lured into adult life by running a brothel and becoming a prostitute herself. Rita's story could be told about any girl around the world with similar hard living conditions.

As for Pecola, she is raped at twelve (while Rita was raped at the age of six). The ordeal of rape is one of the most despicable horrors in today's world. That turpitude of man and its horrible consequences on women, can be found in all societies of the world. The stories about rape by Toni Morrison and Maya Angelou add more connections between America and Africa. Rita was raped by her mother's boyfriend, somebody who should have stood for her father, and Pecola by her own father. By fictionalizing the rape of daughters by fathers, Morrison and Angelou seem to draw people's attention to what psychologists often assert, which is that most rapes ordeals happen within the girls' family circles.

In Africa, it is even possible to talk about a "socially legalized rape" when a girl of thirteen, for instance, is forced to marry and sleep with a man of thirty or more; somebody she may not even know and who could be older than her own father.

That brief analysis has certainly proven that there are connections between Africa and the USA in quite a few domains. That surely reinforces the idea of the global dimensions of American Literature and its representations. Paule Marshall's use of religious rites and supernatural beliefs adds more credibility to the presence of Africa in American World Literature.

\section{Religious Rites and Supernatural Elements in American World Literature}

In her novel Praisesong for the Widow (1983) Paule Marshall depicts some religious rites that are akin to African ones. In Africa, it is generally believed that the dead are not really dead, but they rather live in a supernatural world, and they visit the living as spirits. For Edward Sackey: 
Although the ancestors serve as spirit guardians, their efficacy depends on human fulfilment of responsibility. If the ancestors are disobeyed there could be personal or social disaster. For example, disruption of the continuity between the living and the dead is tantamount to spiritual chaos that could lead to untimely death (Sackey 1991, 393).

When reading Paule Marshall's book, quite a few Africans may take it for granted that it was written for them. In fact, the main character Avey Johnson's renaissance or rebirth throughout the part entitled "Lavé Tête" epitomizes the connection of Africa and the USA after the Bluest Eye and Gather Together in My Name in the field of women's social ordeals. Elizabeth McVeil writes about Praisesong for the Widow:

Female characters are, like the protagonist in Praisesong, undergoing a spiritual metamorphosis, symbolic death and rebirth that will develop these 'raw souls' through their metaphysical striving (McVeil 2009, 185).

The "Lavé Tête" expresses Avey Johnson's obligation to wash the dirt in her life and body; and that ceremony recalls the ritual of the Voodoo that originated in Africa and was taken to the Americas by the enslaved Africans in the $16^{\text {th }}$ and $17^{\text {th }}$ centuries.

The interactions with the ancestors through ceremonies of reconciliation and offerings allow Avey Johnson to leave her former social code and embrace new values and interests. Avey Johnson's sojourn at Carriacou, thus, defines her possibility to deconstruct her false identity and reconstruct a new one, which corresponds to her social and cultural origins.

Such a metamorphosis could be understood as an invitation to Africans living abroad to always bear in mind that they are Africans despite the fact they live far away from home. Africans of the Diaspora should always develop their connections with their land of origin. Such an idea is very much developed in many African societies, where ceremonies of initiations are often organized, so that people, who do not live their true African values, can have the opportunity to discover the culture of their ancestry.

Ceremonies of Voodoo and others in the Sacred Wood, to name but a few, are quite frequent in Africa. Thus, Paule Marshall, through the character of Avey Johnson, seems to remind not only Africans, but also people of most Diasporas of the importance of being constantly connected to their true identities. In so doing, Praisesong for the Widow can be widely read, with much pleasure, in Africa and certainly in other parts of the world. The Bluest Eye, Gather Together in My Name and Praisesong for the Widow have evolved from a national context to a global one. As Paul Giles has explained it: 'Today's American Literature is understood as engaging with the wider world rather than merely with local or national circumstances". (Giles, 2019, 1). The other important aspect worth mentioning is about the supernatural creeds. Paule Marshall writes:

Clangerous, insistent, soaring, the iron was sending out a call loud enough to be heard from one end of the archipelago to the other. Iron calling for its namesake and creator. Until after a time the call was answered. Those among the elderly who, like Lebert Joseph, possessed connaissance could tell. They sensed a presence squatting in the darkness beyond the reach of the gas lamps. Ogun Feraille. Taking his nightly stroll around the island he had heard the sound of the gong-gong and dropped in.

(Marshall, 1983, 246-247).

In that passage, Paule Marshall reconfirms the presence of Africa in her book. Africa is defined by its gods and its cosmogony. Marshall reminds Africans of their true religions which are not Christianity or Islam. She is not probably inviting Africans to abandon their Christian or Islamic monotheistic faiths and go back to their polytheistic ones, but rather to understand and remember their ancestors' creeds to better construct or reconstruct their Africanism.

\section{Conclusion}

Since America is made up by bits of every part of the world, no wonder then, that its title of The New World is more than justified when its literature can be understood as World Literature. The continent of Africa that played a paramount role in the making of the USA can be felt in a lot of American fiction literary works . 
From the Puritan time to our present days, some women and girls in America have undergone quite similar ordeals as African ones under the aegis of a patriarchal order installed by men. Novelists like Nathaniel Hawthorne, Kate Chopin, Toni Morrison and Maya Angelou have not failed to depict the horrible outcomes of such a system on women and girls.

The theory of intersectionality works for some American and African women because of their quite similar ordeals. Apart from the issue of race which is a particular problem in the USA, a lot of women in Africa and many black American women as well, suffer from issues of class, gender and identity.

Finally, cultural references and religious rites, especially in the Southern part of the USA and the Caribbean Islands, contribute to tying the knot between Africa and America within the concept of American World Literature.

\section{References}

[1] Angelou, Maya. 1985, Gather Together in My Name. Washington: Bantam Books.

[2] Chopin, Kate. 2014, The Awakening. New York: Garden City Edition.

[3] Dimock, Wai Chee. 2007, Shades of the Planet, American Literature as World Literature. Princeton: Princeton University Press.

[4] Dimock, Wai Chee. 2006, Through Other Continents. Princeton: Princeton University Press.

[5] Friedman, Susan Stanford. Unthinking Manifest Destiny: Muslim Modernities on Three Continents in Shades of the Planet, American Literature as World Literature. Princeton: Princeton University Press. Edit Dimock Wai Chee.

[6] Giles, Paul. 2007 The Deterritorialization of American Literature in Shades of the Planet, American Literature as World Literature. Princeton: Princeton University Press. Edit Dimock Wai Chee.

[7] Giles, Paul. 2019, American World Literature: An Introduction in Wiley.com/enus/American+world+Literature.

[8] Hawthorne, Nathaniel. 1989, (1850) The scarlet Letter. New York: Bantam Books.

[9] Karlsen, Carol. F. 1989, The Devil in the Shape of a Woman, New York: Wintage Books.

[10] Leo, Jeffrey R Di, 2016, American World Literature in www.Slought.com.

[11] Lugo, Gabriel. 2016, Intersectionality in medium.com/@ellesmythy.

[12] Marshall, Paule. 1983, Praisesong for the Widow, New York: Penguin Books.

[13] McNeil, Elizabeth. 2009, 'The Gullah Seeker's Journey in Paule Marshall's Praisesong for the Widow, MELLUS: Multi-Ethnic Literature of the US, 34.1, 185-2019.

[14] Mendy, Louis. 2018, 'Looping the Loop in Maya Angelou's Gather Together in My Name', Academy of Social Journal, vol 3:01, 1103-1108.

[15] Mendy, Louis. 2014, 'Misconstruction of Love and Lack of Self Esteem in Toni Morrison's The Bluest Eye", The International Journal of Social Science and Humanities Invention, vol 1, issue 9, 773-782.

[16] Mendy, Louis.2017, "A loosing Battle against the Patriarchal Order in Kate Chopin's The Awakening', Collection Bridges, Tome 1 Essays in Honor of Professor Mamadou Kandji, 35-44.

[17] Morrison, Toni. 1972, The Bluest Eye, Washington: Washington Square Press.

[18] Sackey, Edward. 1991, ' Oral Tradition and the African Novel', MFS Modern Fiction Studies, 37:3, 398-407.

[19] Udo Okoronkwo-Chukwu (2016) Brittlepaper.com - Review of Bedfellows by Obinna Odenwe.

[20] www.United Nations Population Fund, 2013. 